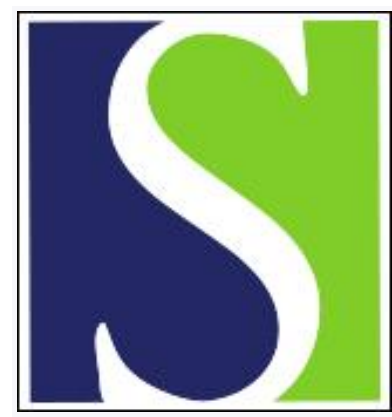

Scand J Work Environ Health 2013;39(4):411-419

https://doi.org/10.5271/sjweh.3336

Published online: 06 Dec 2012, Issue date: 01 Jul 2013

Notification of occupational disease and the risk of work disability: a two-year follow-up study

by Kolstad HA, Christensen MV, Jensen LD, Schlünssen V, Thulstrup AM, Bonde JP

This study suggests that notification of an occupational disease increases the risk of work disability. Compensation systems should ensure that only workers with high odds of compensation are notified and physicians should consider the risk of exclusion from the job market before notifying a patient.

Affiliation: Department of Occupational Medicine, Danish Ramazzini Centre, Aarhus University Hospital, Norrebrogade 44, DK 8000 Aarhus C, Denmark. henkol@rm.dk

The following articles refer to this text: 2013;39(4):420; 2013;39(4):421-422; 2013;39(4):423-424

Key terms: follow-up study; gainful employment; notification of occupational disease; occupational disease; occupational health service; work disability; workers' compensation

This article in PubMed: www.ncbi.nlm.nih.gov/pubmed/23223751 


\title{
Notification of occupational disease and the risk of work disability: a two- year follow-up study
}

\author{
By Henrik A Kolstad, MD, ${ }^{1}$ Michael V Christensen, MA, ${ }^{1}$ Lone Donbæk Jensen, MD, ${ }^{1}$ Vivi Schlünssen, \\ $M D,{ }^{1}$ Ane Marie Thulstrup, MD, ${ }^{1}$ Jens Peter Bonde, MD ${ }^{1,2}$
}

\begin{abstract}
Kolstad HA, Christensen MV, Jensen LD, Schlünssen V, Thulstrup AM, Bonde JP. Notification of occupational disease and the risk of work disability: a two-year follow-up study. Scand J Work Environ Health. 2013;39(4):411419. doi:10.5271/sjweh.3336
\end{abstract}

Objectives The aim of this study was to analyze if notification of an occupational disease increases the risk of work disability.

Methods We included 2304 patients examined at the Department of Occupational Medicine, Aarhus University Hospital, 1998-2005 and followed them for two years. A total of 564 patients were notified of an occupational disease when they were examined at baseline and 1740 patients were not. We obtained weekly information on sick payment, unemployment payment, disability pension, rehabilitation benefit, and other social benefits during the two years of follow-up from a national register. Using Cox regression models, we analyzed notification and adjusted hazard ratios $\left(\mathrm{HR}_{\mathrm{adj}}\right.$ ) of work disability (defined as $>12$ weeks of social benefits during the first or second year of follow-up).

Results Prior to notification, notified patients had higher levels of clinical, occupational, and social characteristics that predict poorer vocational prognosis. Analyses that adjusted for these differences showed an increased risk of work disability following notification for patients who were working when notified at baseline $\left(\mathrm{HR}_{\mathrm{adj}}\right.$ $1.46,95 \%$ CI 1.17-1.82). No effect was seen for patients who were not working.

Conclusions Notification of an occupational disease may, as an unintended side effect, increase the risk of work disability. A cautious interpretation is warranted because data analyses may not fully have accounted for the poorer vocational prognosis already present at baseline.

Key terms gainful employment; occupational health service; workers' compensation.

Workers who contract diseases caused by their work or working conditions have the right to compensation for disability, wage loss, and medical expenses according to most jurisdictions (1). Compensation systems vary between states and countries, but qualification for compensation usually requires that physicians make a notification or workers submit a claim to the compensation authorities. Processing of claims is often long-lasting, may require comprehensive documentation from workers, health and safety representatives, general practitioners, hospitals as well as expert testimony, and may have disabling consequences beyond the health condition that prompted the claim (2). Poorer prognosis following workers' compensation claims has been reported for patients with head injury (3), chronic pain (4), low-back pain (5-14), neck pain (15), carpal tunnel syndrome (16), accidents (17), for a general working population (18), and following surgery for shoulder disorders (1922) and lumbar spine diseases (23), when compared with patients not involved in a compensation claim. Affected outcomes have included patient satisfaction, function, quality of life, mental health, cognition, symptoms, return to work, and days away from work (17).

Studies of the health effects of worker's compensation

\footnotetext{
${ }^{1}$ Department of Occupational Medicine, Danish Ramazzini Centre, Aarhus University Hospital, Aarhus, Denmark.

2 Department of Occupational and Environmental Medicine, Copenhagen University Hospital, Bispebjerg, Denmark

Correspondence to: Henrik A Kolstad, Department of Occupational Medicine, Danish Ramazzini Centre, Aarhus University Hospital, Norrebrogade 44, DK 8000 Aarhus C, Denmark. [E-mail: henkol@rm.dk]
} 
notifications have to be interpreted with caution because of the inherited methodological weaknesses of observational studies, and a recent meta-review concluded that the evidence that compensation is associated with subsequent poorer health is equivocal (17). In addition to workers experiencing more strenuous working conditions, it is expected that disabled workers are more likely to be involved in a compensation claim than those less disabled or those with less strenuous working conditions, even if they are diagnosed with the same disorder $(24,25)$. This may confound associations between notification status and subsequent health and employment in line with confounding by indication. Confounding by indication occurs when a symptom or sign of disease is an indication of a given intervention and is therefore associated with both the intervention and a higher probability of the outcome (26). To avert confounding by indication, the patient groups compared must be strictly matched or analyses rigorously adjusted by health status as well as working conditions $(27,28)$.

In Denmark, all employees are covered by a worker's compensation insurance that covers occupational accidents and occupational diseases. The insurance is financed by the employers, administrated by a governmental board, the National Board of Industrial Injuries, and includes compensation for disability, wage loss, death, and medical expenses (29). These benefits are beyond medical treatment, sick leave compensation, disability pension, rehabilitation benefits, and unemployment payments that citizens may obtain regardless of any tort, culpa, cause, or reason. In general, diseases included in the Danish official list of occupational diseases are recognized if exposure intensity, duration, and timing is sufficient and no other factors are more likely to have caused the disease (30). During the past 20 years, several disorders defined by subjective complaints without well-defined objective criteria [such as chronic neck and shoulder pain (cervicobrachial syndrome) and persistent low-back pain] have become eligible for compensation. The Danish list also includes diseases with a low attributable fraction given exposure as hip osteoarthritis (the relative risk following many years of heavy lifting is $<1.5)(30,31)$. By law, all physicians and dentists are obliged to notify every patient with any suspected occupational disease to the compensation board.

Annually, about 18000 compensation claims for occupational diseases are notified in Denmark, corresponding to $0.6 \%$ of all employed workers, and about $25 \%$ are recognized as a compensable condition (32). Compared with several other European countries, the number of notified workers is high, while the compensation proportion is low (33). Compensated workers received on average a total benefit of 30000 euros in 2011.

Using a historical cohort of patients examined at a department of occupational medicine of a university hospital, the aim of this study was to analyze whether notification of occupational disease, as an unintended side effect, increases the risk of work disability.

\section{Methods}

This was a follow-up study of patients examined for the first time at the Department of Occupational Medicine, Aarhus University Hospital, 1998-2005. Baseline was the day of examination when a patient was notified (or not notified) of an occupational disease, and the followup period was two years.

\section{Patients}

Candidates for the study were all 5394 patients examined following referral from the general practitioner, other medical specialists, labor union representatives, or workplaces. We excluded patients who (i) were not Danish residents $(\mathrm{N}=17)$, (ii) were $<16$ years or $>59$ years of age $(\mathrm{N}=367)$, (iii) received disability pension ( $\mathrm{N}=112$ ), (iv) only requested risk assessment related to their work during pregnancy $(\mathrm{N}=367)$, or $(\mathrm{v})$ provided no information on work status $(\mathrm{N}=218)$. As the underlying timescale for the analysis was a year, we also excluded 6 patients who emigrated and 27 patients who died during the first year of follow-up. A total of 1977 patients had already been notified of an occupational disease prior to the examination, and 2304 patients remained for further analysis.

\section{Clinical examination}

The examination included medical, employment and exposure history, and a physical examination. If necessary the work place was visited for additional exposure information. One of twenty-one physicians undertook the examination; the majority were specialists in occupational medicine, or one of two psychologists in case of stress-related conditions.

At the time of the examination, the following were recorded as part of the routine registration: (i) the International Classification of Diseases (ICD-10) diagnosis made by the examining physician or psychologist, (ii) employment status (working, unemployed, sick-listed, or receiving social security benefits), (iii) occupation [5-level Danish version of the International Standard Classification of Occupations (ISCO), 2nd edition, 1968 (34)], (iv) occupational exposures [6-level Danish classification of occupational exposures, (35)], and (v) referring institution. During 2004-2005, 385 patients completed a Danish version of the short form 36 (SF$36)$ health survey questionnaire $(36,37)$ prior to the 
consultation and were classified by measures of generic functional status: vitality, mental health, general health, physical function, and bodily pain, as well as the physical components summary (PCS) and the mental components summary (MCS).

\section{Work disability}

Sick payment, unemployment payment, disability pension, rehabilitation benefit, and other social benefits are accessible for all Danish citizens independently of the worker's compensation insurance. The Ministry of Employment keeps record of these payments for all citizens for every calendar year and calendar week. We obtained this information for all patients for the two years preceding notification (baseline) and the two years following notification (the follow-up period). We computed the number of weeks each patient received any payments during the last and the second last year before baseline and during the first and the second year of follow-up. We defined work disability as a year with $>12$ weeks of sick payment, unemployment payment, disability pension, rehabilitation benefit, or other social benefits (38). The Minstry of Employment provided no information on diagnosis for these payments, and we had no information on whether the patients were granted worker's compensation from the National Board of Industrial Injuries.

\section{Statistical methods}

We compared characteristics of notified and not notified patients at baseline by Chi square tests (proportions) and Wilcoxon rank sum test (medians). We estimated hazard ratios (HR) of work disability during follow-up by workers' notification status at baseline in Cox regression models. The underlying timescale for this analysis was a year since our definition of work disability required a full year of follow-up. Each patient was followed until he or she fulfilled the criteria of work disability during the first or the second year of follow-up. The 18 patients who died or emigrated during the second year of followup were censored at the end of the first year.

We adjusted for sex, age (continuous), calendar year (8 levels), work disability during the last year before baseline (yes/no), work disability during the second last year before baseline (yes/no), diagnosis (27 diagnoses or diagnostic groups), occupation (9 occupational groups), employment status at baseline (working, unemployed, sick-listed, or receiving social security benefits), exposure (7 levels), referring institution (general practitioner, labor union, or hospital department) and examining physician or psychologist (23 examiners). Covariates that affected the HR $\leq 10 \%$ were deleted from the full model and this comprised the final model (39). We did separate analyses for patients who were working or not working (unemployed, sick-listed, or receiving social security benefits) at baseline. We also did analyses that adjusted for the PCS and the MCS. In these analyses, we only included the 385 patients who completed the SF-36 questionnaire and furthermore collapsed the 9 occupational groups into 2 categories (blue- and whitecollar worker), the 27 diagnostic groups into 4 major categories, and the 2 categories of unemployed and sicklisted into 1 variable for working status because of the limited number of patients. All analyses were conducted with SAS statistical software version 9.3 (SAS Institute, Inc, Cary, North Carolina).

\section{Results}

A total of 564 patients were notified of an occupational disease and 1740 were not. Table 1 shows that notified patients differed from those not notified by most characteristics at baseline. They were more often men, older, sick-listed, unemployed, receiving social security benefit, and diagnosed with irritant contact dermatitis, carpal tunnel syndrome, Raynaud's syndrome, dorsalgia, shoulder lesions, or other diseases of the musculoskeletal system and connective tissue. They were less often classified with an R (symptoms, signs and abnormal clinical and laboratory findings) or Z (factors influencing health status and contact with health services) ICD-10 diagnosis. Patients with an occupation as farm or gardening, industrial, construction, or blue-collar worker were more often notified of an occupational disease. This was also the case for patients referred by their labor union while there was no trend in notification rate by calendar year. Among the subset of patients who completed the SF-36 questionnaire, the notified patients reported poorer physical health, while there was no difference with respect to mental health between notified and not notified patients. The proportion that had experienced work disability during the last year before notification was higher for the notified (47.9\%) than not notified patients $(40.3 \%, \mathrm{P}=0.002)$, but no difference was seen for the second last year before notification ( $27.3 \%$ versus $25.8 \%, \mathrm{P}=0.240$ ).

After two years of follow-up, 397 (70.4\%) of the notified patients and 1038 (59.6\%) of the non-notified patients experienced work disability (table 2). For this two-year period, the median duration off-work was 56 and 31 weeks for the notified and not notified patients, respectively. Work disability during the last year before notification was strongly associated with employment status at the time of notification, as expected, and the differences between the notified and the non-notified patients diminished when data were stratified by employment status. 
Table 1. Baseline characteristics of 564 patients notified and 1740 patients not notified of occupational disease, Aarhus, Denmark, 1998-2005. [ICD=International Classification of Diseases]

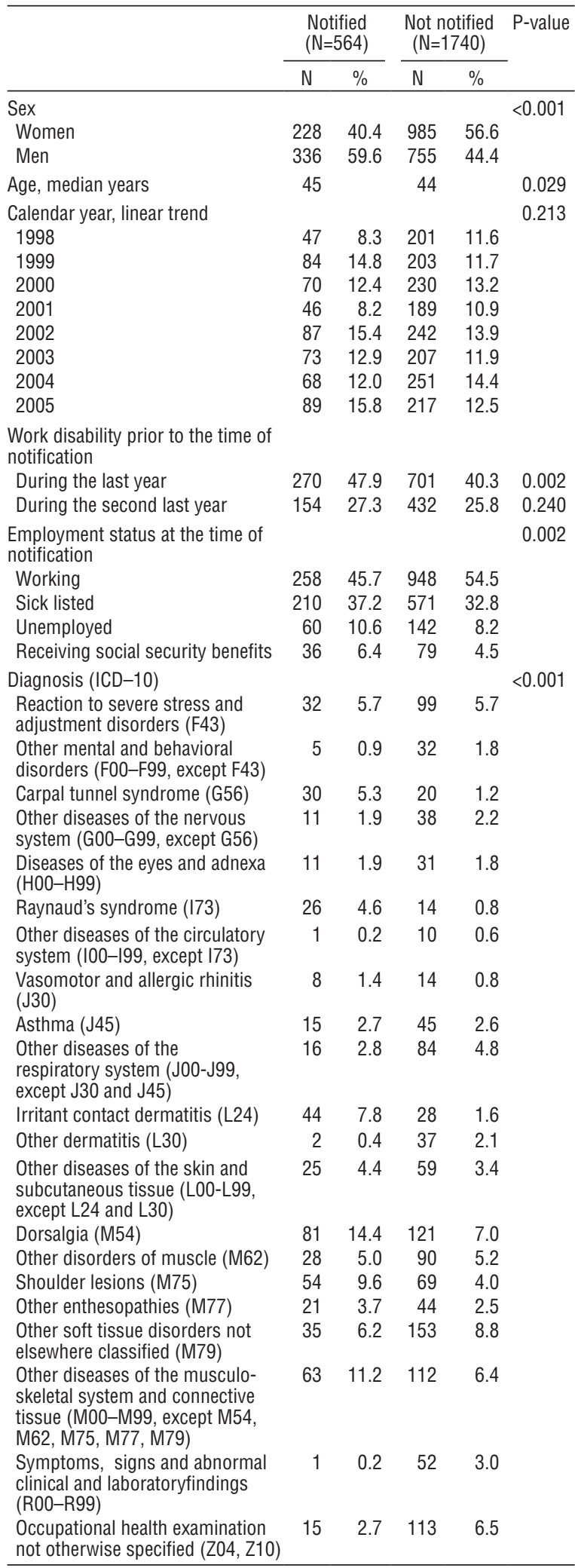

Table 1. Continued

\begin{tabular}{|c|c|c|c|c|c|}
\hline & \multicolumn{2}{|c|}{$\begin{array}{l}\text { Notified } \\
(\mathrm{N}=564)\end{array}$} & \multicolumn{2}{|c|}{$\begin{array}{l}\text { Not notified } \\
(\mathrm{N}=1740)\end{array}$} & \multirow[t]{2}{*}{ P-value } \\
\hline & $\mathrm{N}$ & $\%$ & $\mathrm{~N}$ & $\%$ & \\
\hline $\begin{array}{l}\text { Problems related to employment } \\
\text { and unemployment (Z56) }\end{array}$ & 11 & 2.0 & 191 & 11.0 & \\
\hline $\begin{array}{l}\text { Other factors influencing health } \\
\text { status and contact with health } \\
\text { services (Z00-Z99, except Z04, } \\
\text { Z10, Z56 and Z57) }\end{array}$ & 7 & 1.2 & 116 & 6.7 & \\
\hline Other diagnosis (A00-Z99) & 15 & 2.7 & 49 & 2.8 & \\
\hline No diagnosis recorded & 0 & 0.0 & 5 & 0.3 & \\
\hline $\begin{array}{l}\text { Diagnosis characterized by } \\
\text { objective findings (G56, I73, } \\
\mathrm{J} 45, \mathrm{~L} 24, \mathrm{~L} 30)^{\mathrm{a}}\end{array}$ & 117 & 20.7 & 144 & 8.3 & $<0.001$ \\
\hline Occupation & & & & & $<0.001$ \\
\hline Farm and gardening worker & 30 & 5.3 & 45 & 2.6 & \\
\hline Industrial worker & 171 & 30.3 & 362 & 20.8 & \\
\hline Unskilled worker & 41 & 7.3 & 140 & 8.1 & \\
\hline Transportation worker & 40 & 7.1 & 106 & 6.1 & \\
\hline Construction worker & 103 & 18.3 & 131 & 7.5 & \\
\hline $\begin{array}{l}\text { Restaurant and other service } \\
\text { worker }\end{array}$ & 46 & 8.2 & 159 & 9.1 & \\
\hline Office workers and shop attendant & 44 & 7.8 & 270 & 15.5 & \\
\hline Nurses and teacher & 69 & 12.2 & 432 & 24.8 & \\
\hline No or unknown occupation & 20 & 3.6 & 95 & 5.5 & \\
\hline Blue- versus white-collar worker & & & & & $<0.001$ \\
\hline White-collar worker & 113 & 20.0 & 702 & 40.3 & \\
\hline Blue-collar worker & 431 & 76.4 & 943 & 54.2 & \\
\hline No or unknown occupation & 20 & 3.6 & 95 & 5.5 & \\
\hline Exposure & & & & & $<0.001$ \\
\hline Biological & 13 & 2.3 & 17 & 1.0 & \\
\hline Chemical & 76 & 13.5 & 359 & 20.6 & \\
\hline Ergonomic & 287 & 50.9 & 453 & 26.0 & \\
\hline Physical & 56 & 9.9 & 112 & 6.4 & \\
\hline Psychological & 33 & 5.9 & 113 & 6.5 & \\
\hline Other & 52 & 9.2 & 122 & 7.0 & \\
\hline No exposure & 4 & 0.7 & 163 & 9.4 & \\
\hline Missing information & 43 & 7.6 & 401 & 23.1 & \\
\hline Referring institution & & & & & $<0.001$ \\
\hline General practitioner & 307 & 54.2 & 1070 & 61.5 & \\
\hline Labor union & 202 & 35.8 & 478 & 27.5 & \\
\hline Hospital department & 55 & 10.0 & 192 & 11.0 & \\
\hline Examination by & & & & & $<0.001$ \\
\hline Physician & 523 & 92.7 & 1488 & 85.5 & \\
\hline Psychologist & 41 & 7.3 & 252 & 14.5 & \\
\hline \multicolumn{6}{|l|}{ Self-assessed general health b } \\
\hline $\begin{array}{l}\text { Physical components summary } \\
\text { (PCS), median score }\end{array}$ & 36.1 & & 40.0 & & 0.008 \\
\hline $\begin{array}{l}\text { Mental components summary } \\
\text { (MCS), median score }\end{array}$ & 40.5 & & 42.4 & & 0.719 \\
\hline Vitality, median score & 30.0 & & 35.0 & & 0.126 \\
\hline Mental health, median score & 56.0 & & 58.0 & & 0.875 \\
\hline General health, median score & 47.0 & & 55.0 & & 0.005 \\
\hline $\begin{array}{l}\text { Physical functioning, median } \\
\text { score }\end{array}$ & 75.0 & & 80.0 & & 0.036 \\
\hline Bodily pain, median score & 32.0 & & 41.0 & & 0.011 \\
\hline
\end{tabular}

a Carpal tunnel syndrome, Raynaud's syndrome, asthma, irritant contact dermatitis, and other dermatitis.

${ }^{\mathrm{b}}$ A total of 95 notified and 290 not notified patients completed the SF-36 self-assessment. 
Table 2. Notification of occupational disease and hazard ratios (HR) of work disability during two years of follow-up by baseline working

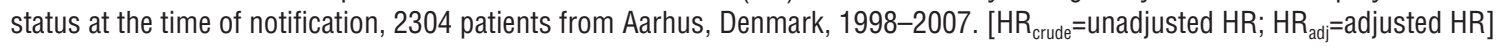

\begin{tabular}{|c|c|c|c|c|c|c|c|c|c|c|c|}
\hline \multirow{3}{*}{$\begin{array}{l}\text { Baseline working status / } \\
\text { notification status }\end{array}$} & \multirow{3}{*}{$\begin{array}{c}\begin{array}{c}\text { All } \\
\text { patients }\end{array} \\
\mathrm{N}\end{array}$} & \multirow{2}{*}{\multicolumn{2}{|c|}{$\begin{array}{c}\text { Work disabled } \\
\text { during the last } \\
\text { year before } \\
\text { notification }\end{array}$}} & \multicolumn{8}{|c|}{ Work disabled during the two years after notification } \\
\hline & & & & \multicolumn{2}{|c|}{ Total } & \multicolumn{2}{|c|}{ Model I } & \multicolumn{2}{|c|}{ Model II a } & \multicolumn{2}{|c|}{ Model III b } \\
\hline & & $\mathrm{N}$ & $\%$ & $\mathrm{~N}$ & $\%$ & $\mathrm{HR}_{\text {crude }}$ & $95 \% \mathrm{Cl}$ & $H R_{\text {adj }}$ & $95 \% \mathrm{Cl}$ & $H R_{\text {adj }}$ & $95 \% \mathrm{Cl}$ \\
\hline \multicolumn{12}{|l|}{ All } \\
\hline Not notified & 1740 & 701 & 40.3 & 1038 & 59.7 & 1.00 & & 1.00 & & 1.00 & \\
\hline Notified & 564 & 270 & 47.9 & 397 & 70.4 & 1.22 & $1.08-1.37$ & 1.13 & $0.99-1.30$ & 1.11 & $0.99-1.27$ \\
\hline \multicolumn{12}{|l|}{ Not working } \\
\hline Not notified & 792 & 522 & 65.9 & 701 & 88.5 & 1.00 & & 1.00 & & 1.00 & \\
\hline Notified & 306 & 211 & 69.0 & 273 & 89.2 & 1.01 & $0.88-1.16$ & 0.99 & $0.85-1.17$ & 0.99 & $0.85-1.15$ \\
\hline \multicolumn{12}{|l|}{ Working } \\
\hline Not notified & 948 & 179 & 18.9 & 337 & 35.6 & 1.00 & & 1.00 & & 1.00 & \\
\hline Notified & 258 & 59 & 22.9 & 124 & 48.1 & 1.41 & $1.15-1.75$ & 1.45 & $1.12-1.83$ & 1.46 & $1.17-1.82$ \\
\hline
\end{tabular}

a Adjusted for sex (2 levels), age (continuous), calendar year (8 levels), diagnosis (27 levels), work disability during the last year (2 levels), work disability during the second last year (2 levels), sick-listed at the time of the examination (2 levels), unemployed at the time of the examination (2 levels), occupation (9 levels), referring institution (3 levels), exposure (7 levels), and identity of examining physician or psychologist (17 levels).

${ }^{\mathrm{b}}$ Adjusted for sex (2 levels), work disability during the last year (2 levels), work disability during the second last year (2 levels), work status at the time of the examination (2 levels), and exposure (7 levels).

The overall crude HR of work disability was 1.22 [95\% confidence interval (95\% CI) $1.08-1.37$ ] (table 2). In the fully adjusted model, this estimate was reduced to 1.13 (95\% CI 0.99-1.30). The final model, that included sex, employment status at baseline, work disability during the last and second last year prior to baseline, and occupational exposures, showed a HR of 1.11 (95\% CI 0.99-1.27).

Analyses stratified by employment status at the time of notification revealed a crude HR of $1.41(95 \% \mathrm{CI}$ $1.15-1.75)$ and a finally adjusted HR of 1.46 (95\% CI 1.17-1.82) among working patients (table 2). No effect of notification was seen for patients not working.

Among patients working at baseline, comparable effects of notification were seen across the major diagnostic entities as well as for diseases characterized by objective findings (table 3 ).

The HR of work disability adjusted for the PCS and MCS components was 2.07 (95\% CI 1.17-3.66) among patients working at the time of notification, while no effect was seen for those not working, but this analysis included only 385 patients (table 4).

An additional analysis (data not shown) compared the prognosis of the 1977 patients who had been notified prior to the examination at the department of occupational medicine with the 1740 patients who had not been notified during the examination at the department. For patients working at the time of the examination (1032 notified versus 948 not notified patients), we observed an adjusted HR of work disability of 1.22 (95\% CI $0.99-1.52)$. This HR was 0.98 (95\% CI $0.86-1.10)$ for patients not working (945 notified versus 792 not notified patients).

\section{Discussion}

We observed an increased risk of work disability following notification of an occupational disease, but only among patients who were working when notified at baseline. No effect was seen for patients who were unemployed, sick-listed, or received social security benefits at baseline, but only about $10 \%$ of these patients were not work disabled and gainfully employed after two years of follow-up. The effect among patients who were working at baseline seemed to be independent of diagnosis and the presence of objective clinical findings. These overall results were in line with several previous reports of the effect of compensation claims and notifications on return to work or work status among patients with musculoskeletal system and connective tissue disorders (5-7, 9, $10,12,14)$. We are not aware of earlier studies, which have analyzed the effect of notification of respiratory, skin, or mental diseases.

At baseline, notified patients presented higher levels of clinical, occupational and social characteristics expected to predict poorer vocational prognosis $(9$, $14,19,21,24)$. The key question is if we sufficiently accounted for these differences in the adjusted analyses of work disability. We were able to include more detailed information on occupation, occupational exposures, and prior work disability than done in most previous studies. The SF-36 questionnaire provided valid information on disease severity and functional status beyond diagnoses (37-40). But we only had access to this information for a subsample of patients. We had no information on lifestyle factors, expectations, personality trait, and education that may also have predicted work disability $(8,10)$. On the other hand, most patients referred to 
Table 3. Notification ofoccupational disease and hazard ratio (HR) of work disability by four major diagnostic categories and a category of diagnoses characterized by objective findings among patients working at baseline at the time of notification, Aarhus, Denmark, $1998-2007$. [HR $\mathrm{Hrude}_{\text {e }}=$ unadjusted $\mathrm{HR} ; \mathrm{HR}_{\mathrm{adj}}=$ adjusted HR.]

\begin{tabular}{|c|c|c|c|c|c|c|c|c|c|c|c|}
\hline \multirow[t]{3}{*}{ Baseline notification status } & \multirow{3}{*}{$\begin{array}{c}\begin{array}{c}\text { All } \\
\text { patients }\end{array} \\
\mathrm{N}\end{array}$} & \multirow{2}{*}{\multicolumn{2}{|c|}{$\begin{array}{c}\text { Work disabled } \\
\text { during the last } \\
\text { year before } \\
\text { notification }\end{array}$}} & \multicolumn{8}{|c|}{ Work disabled during the two years after notification } \\
\hline & & & & \multicolumn{2}{|c|}{ Total } & \multicolumn{2}{|c|}{ Model I } & \multicolumn{2}{|c|}{ Model II a } & \multicolumn{2}{|c|}{ Model III b } \\
\hline & & $\mathrm{N}$ & $\%$ & $\mathrm{~N}$ & $\%$ & $\mathrm{HR}_{\text {crude }}$ & $95 \% \mathrm{Cl}$ & $\mathrm{HR}_{\mathrm{adj}}$ & $95 \% \mathrm{Cl}$ & $H R_{a d}$ & $95 \% \mathrm{Cl}$ \\
\hline \multicolumn{12}{|c|}{$\begin{array}{l}\text { Mental and behavioral disorder } \\
\text { (ICD-10, F00-F99) }\end{array}$} \\
\hline Not notified & 35 & 17 & 48.6 & 15 & 42.9 & 1.00 & & 1.00 & & 1.00 & \\
\hline Notified & 5 & 2 & 40.0 & 3 & 60.0 & 1.46 & $0.42-5.06$ & 2.78 & $0.37-20.83$ & 1.39 & $0.36-5.35$ \\
\hline \multicolumn{12}{|c|}{$\begin{array}{l}\text { Diseases of the respiratory system } \\
\text { (ICD-10, J00-J99) }\end{array}$} \\
\hline Not notified & 102 & 22 & 21.6 & 32 & 31.4 & 1.00 & & 1.00 & & 1.00 & \\
\hline Notified & 16 & 2 & 12.5 & 7 & 43.8 & 1.45 & $0.64-3.28$ & 1.83 & $0.61-5.51$ & 1.61 & $0.68-3.82$ \\
\hline \multirow{2}{*}{\multicolumn{12}{|c|}{$\begin{array}{l}\text { Diseases of the skin and } \\
\text { subcutaneous tissue (ICD-10, L00-L99) }\end{array}$}} \\
\hline & & & & & & & & & & & \\
\hline Not notified & 106 & 9 & 8.5 & 24 & 22.6 & 1.00 & & 1.00 & & 1.00 & \\
\hline Notified & 53 & 11 & 20.8 & 20 & 37.7 & 1.75 & $0.96-3.16$ & 2.09 & $0.80-5.48$ & 1.84 & $0.92-3.69$ \\
\hline \multicolumn{12}{|c|}{$\begin{array}{l}\text { Diseases of the musculoskeletal system and } \\
\text { connective tissue (ICD-10, M00-M99) }\end{array}$} \\
\hline Not notified & 279 & 67 & 24.0 & 121 & 42.7 & 1.00 & & 1.00 & & 1.00 & \\
\hline Notified & 108 & 34 & 31.5 & 63 & 58.3 & 1.41 & $1.04-1.91$ & 1.40 & $0.98-1.99$ & 1.37 & $0.99-1.90$ \\
\hline \multicolumn{12}{|c|}{$\begin{array}{l}\text { Diseases characterized by objective findings } \\
\text { (ICD-10, G56, I73, J45, L24, L30) }\end{array}$} \\
\hline Not notified & 104 & 14 & 13.5 & 26 & 25.0 & 1.00 & & 1.00 & & 1.00 & \\
\hline Notified & 80 & 11 & 13.8 & 28 & 35.0 & 1.33 & $0.79-2.24$ & 1.75 & $0.82-3.73$ & 1.46 & $0.80-2.66$ \\
\hline
\end{tabular}

Table 4. Notification of occupational disease and hazard ratio (HR) of work disability by baseline working status at the time of notification. Results from a subset of 385 patients who reported general physical and mental health by completing the SF-36 questionnaire prior to notification, Aarhus, Denmark, 1998-2007. [HR crude $=$ unadjusted HR; $\mathrm{HR}_{\mathrm{adj}}=$ adjusted HR.]

\begin{tabular}{|c|c|c|c|c|c|c|c|c|c|c|c|}
\hline \multirow{3}{*}{$\begin{array}{l}\text { Baseline working status / } \\
\text { notification status }\end{array}$} & \multirow{3}{*}{$\begin{array}{c}\begin{array}{c}\text { All } \\
\text { patients }\end{array} \\
\frac{\mathrm{N}}{}\end{array}$} & \multirow{2}{*}{\multicolumn{2}{|c|}{$\begin{array}{c}\text { Work disabled } \\
\text { during the last } \\
\text { year before } \\
\text { notification } \\
\end{array}$}} & \multicolumn{8}{|c|}{ Work disabled during the two years after notification } \\
\hline & & & & \multicolumn{2}{|c|}{ Total } & \multicolumn{2}{|c|}{ Model I } & \multicolumn{2}{|c|}{ Model II a } & \multicolumn{2}{|c|}{ Model III b } \\
\hline & & $\mathrm{N}$ & $\%$ & $\mathrm{~N}$ & $\%$ & $\mathrm{HR}_{\text {crude }}$ & $95 \% \mathrm{Cl}$ & $H R_{\text {adj }}$ & $95 \% \mathrm{Cl}$ & $H R_{\text {adj }}$ & $95 \% \mathrm{Cl}$ \\
\hline \multicolumn{12}{|l|}{ All } \\
\hline Not notified & 290 & 140 & 48.3 & 189 & 65.2 & 1.00 & & 1.00 & & 1.00 & \\
\hline Notified & 95 & 47 & 49.5 & 71 & 74.7 & 1.18 & $0.90-1.55$ & 1.13 & $0.83-1.54$ & 1.12 & $0.84-1.50$ \\
\hline \multicolumn{12}{|l|}{ Not working } \\
\hline Not notified & 158 & 112 & 70.9 & 141 & 89.2 & 1.00 & & 1.00 & & 1.00 & \\
\hline Notified & 59 & 41 & 69.5 & 52 & 88.1 & 0.99 & $0.72-1.36$ & 0.97 & $0.68-1.38$ & 0.97 & $0.70-1.36$ \\
\hline \multicolumn{12}{|l|}{ Working } \\
\hline Not notified & 132 & 28 & 21.2 & 48 & 36.4 & 1.00 & & 1.00 & & 1.00 & \\
\hline Notified & 36 & 6 & 16.7 & 19 & 52.8 & 1.60 & $0.94-2.73$ & 2.63 & $1.30-5.31$ & 2.07 & $1.17-3.66$ \\
\hline
\end{tabular}

${ }^{a}$ Adjusted for sex (2 levels), age (continuous), calendar year (8 levels), diagnosis (4 levels), work disability during the last year (2 levels), work disability during the second last year (2 levels), work status (2 levels), occupation (3 levels), referring institution (3 levels), exposure (7 levels), identity of examining physician or psychologist (9 levels), physical component summary (pcs), and mental component summary (mcs).

${ }^{\mathrm{b}}$ Adjusted for sex (2 levels), diagnosis (4 levels), work disability during the last year (2 levels), physical component summary (PCS) and mental component summary (MCS). 
this clinic of occupational medicine were blue-collar workers or middle-class; white-collar workers and few professionals or managers and factors related to social class were thus expected to be more homogenous than in the general population, and this should have reduced confounding. Introducing the potential confounders that we had access to into the statistical models only slightly affected HR and not always towards lower values. This does not indicate strong confounding effects. Residual confounding not captured in our adjusted models cannot, on the other hand, be ruled out in an observational study such as this. In particular, we were unable to adjust for physical and mental job demands, which obviously are linked to notification but are most likely also linked to the outcome. Most occupational disorders are chronic or recurrent and demanding job tasks and/or bad working conditions may, all things being equal, have impeded options for maintaining gainful employment.

All patients were included from the day it was decided to notify the workers' compensation board. From this day, follow-up was complete for notified and not notified patients during the subsequent two years except for the few patients who emigrated or died. This is expected to have increased the likelihood of detecting a true effect compared with previous studies that started follow-up on an arbitrary point in time after the notifications were made

Work disability was based on complete register data of unemployment payments, disability pension, sick pay, rehabilitation benefits, or other social benefits accessible for all Danish citizens. Thus differential reporting of outcome should not have biased results. Criteria for receiving these payments as well as notification for occupational disease may have changed during the study period and thus have effected results. We therefore adjusted all analyses for calendar year. Due to the prospective design, differential reporting of neither notifications nor potential confounders were an issue.

Even if the patients included in this study were a selected sample of persons notified to the workers' compensation board, the occupational composition is expected to have been comparable to all notified persons (32), and it may be reasonable to generalize results to this population and not only to those referred to a hospital department of occupational medicine.

The mechanisms responsible for the suggested unintended effect are probably complex. Californian workers' compensation data have shown that administrative delays increase the risk of chronic disability (40). A recent review concluded that the compensation process following occupational and traffic accidents slightly impair mental health when account is taken for mental health problems already present at baseline (41). The authors suggested that this effect may be attributed to secondary gain and secondary victimization. Others have stressed the adverse effects of attorney involvement, but attorneys are rarely involved in compensation notifications in Denmark (42). One may speculate that health conditions defined only by subjective symptoms are more susceptible to such mechanism but we did not find support for this.

Workers' compensation notification signals that work may threaten workers' health and for that reason it is reasonable to anticipate that notified workers are cautious about continuing their present job. A physician or health and safety or labor union representative may also recommend them to quit the job. If colleagues have received compensation, this may further underpin the perception of the job as hazardous. And such experiences probably overrule epidemiologically based arguments about risk and prognosis.

The Danish list of occupational diseases includes health conditions with different levels of empirical evidence (30). The labor movement as well as socially indignant physicians have seen the inclusion of new diseases on the list of occupational diseases as a means to improve primary prevention as well as workers' social and working conditions (43). Our results suggest that the achievements may be bought at a price (44). In Denmark, three out of four notified patients are not compensated and end up with the suggested side effects only. The findings of this study underpin the need for actions that effectively reduce administrative delays in the compensation system and for changes of notification and acknowledgment procedures to ensure that only workers with high odds of compensation are notified. Furthermore, physicians and others in each individual case have to consider the risk of exclusion from the job market and thus the net gain for the patient before making a notification.

Our results are probably not only relevant for the Danish setting, but also other countries or states with comparable workers' compensation, social, and healthcare systems, such as other Scandinavian countries, but may not apply elsewhere (eg, when workers' compensation systems are the only access to healthcare or sick pay).

To conclude, this study suggests that notification of occupational disease, as an unintended side effect, increases the risk of work disability for patients who are working. A cautious interpretation is warranted because data analyses may not fully have accounted for the poorer vocational prognosis already present at baseline.

\section{References}

1. Ison TG. Workers' compensation systems. In: Stellman JM, editor. Encyclopaedia of occupational health and safety. 4 ed. Geneva: International labour Office, ILO, 1998:25.2-25.24. 
2. Demble AE. Occupation and disease. How social factors affect the conception of work-related diseases. New Haven: Yale University Press; 1996.

3. Binder LM, Rohling ML. Money matters: a meta-analytic review of the effects of financial incentives on recovery after closed-head injury. Am J Psychiatry 1996;153:7-10.

4. Teasell RW. Compensation and chronic pain. Clin J Pain 2001;17:S46-S64. http://dx.doi.org/10.1097/00002508200112001-00011

5. Coste J, Delecoeuillerie G, Cohen de LA, Le Parc JM, Paolaggi JB. Clinical course and prognostic factors in acute low back pain: an inception cohort study in primary care practice. BMJ 1994;308:577-80. http://dx.doi.org/10.1136/ bmj.308.6928.577.

6. Gatchel RJ, Polatin PB, Mayer TG. The dominant role of psychosocial risk factors in the development of chronic low back pain disability. Spine (Phila Pa 1976) 1995;20:2702-9.

7. Atlas SJ, Chang Y, Kammann E, Keller RB, Deyo RA, Singer DE. Long-term disability and return to work among patients who have a herniated lumbar disc: the effect of disability compensation. J Bone Joint Surg Am 2000;82:4-15.

8. Steenstra IA, Verbeek JH, Heymans MW, Bongers PM. Prognostic factors for duration of sick leave in patients sicklisted with acute low back pain: a systematic review of the literature. Occup Environ Med 2005;62:851-60. http://dx.doi. org/10.1136/oem.2004.015842.

9. Atlas SJ, Chang Y, Keller RB, Singer DE, Wu YA, Deyo RA. The impact of disability compensation on long-term treatment outcomes of patients with sciatica due to a lumbar disc herniation. Spine (Phila Pa 1976) 2006;31:3061-9.

10. Iles RA, Davidson M, Taylor NF. Psychosocial predictors of failure to return to work in non-chronic non-specific low back pain: a systematic review. Occup Environ Med 2008;65:50717. http://dx.doi.org/10.1136/oem.2007.036046.

11. Rasmussen C, Leboeuf-Yde C, Hestbaek L, Manniche C. Poor outcome in patients with spine-related leg or arm pain who are involved in compensation claims: a prospective study of patients in the secondary care sector. Scand J Rheumatol 2008;37:462-8. http://dx.doi. org/10.1080/03009740802241709.

12. Jensen OK, Nielsen CV, Stengaard-Pedersen K. One-year prognosis in sick-listed low back pain patients with and without radiculopathy. Prognostic factors influencing pain and disability. Spine J 2010;10:659-75. http://dx.doi. org/10.1016/j.spinee.2010.03.026.

13. Carreon LY, Glassman SD, Kantamneni NR, Mugavin MO, Djurasovic M. Clinical outcomes after posterolateral lumbar fusion in workers' compensation patients: a case-control study. Spine (Phila Pa 1976) 2010;35:1812-7.

14. Atlas SJ, Tosteson TD, Blood EA, Skinner JS, Pransky GS, Weinstein JN. The impact of workers' compensation on outcomes of surgical and nonoperative therapy for patients with a lumbar disc herniation: SPORT. Spine (Phila Pa 1976) 2010;35:89-97.

15. Hestbaek L, Rasmussen C, Leboeuf-Yde C. Financial compensation and vocational recovery: a prospective study of secondary care neck and back patients. Scand J Rheumatol 2009;38:481-7. http://dx.doi. org/10.3109/03009740902895735.

16. Sperka P, Cherry N, Burnham R, Beach J. Impact of compensation on work outcome of carpal tunnel syndrome. Occup Med (Lond) 2008;58:490-5. http://dx.doi.org/10.1093/ occmed/kqn099.

17. Spearing NM, Connelly LB. Is compensation "bad for health"? A systematic meta-review. Injury 2011;42:15-24. http:// dx.doi.org/10.1016/j.injury.2009.12.009.

18. Haahr JP, Frost P, Andersen JH. Predictors of health related job loss: a two-year follow-up study in a general working population. J Occup Rehabil 2007;17:581-92. http://dx.doi. org/10.1007/s10926-007-9106-Z.

19. Balyk R, Luciak-Corea C, Otto D, Baysal D, Beaupre L. Do outcomes differ after rotator cuff repair for patients receiving workers' compensation? Clin Orthop Relat Res 2008;466:3025-33. http://dx.doi.org/10.1007/s11999-0080475-1.

20. Koljonen P, Chong C, Yip D. Difference in outcome of shoulder surgery between workers' compensation and nonworkers' compensation populations. Int Orthop 2009;33:315-20. http:// dx.doi.org/10.1007/s00264-007-0493-8.

21. Henn RF, III, Kang L, Tashjian RZ, Green A. Patients with workers' compensation claims have worse outcomes after rotator cuff repair. J Bone Joint Surg Am 2008;90:2105-13. http://dx.doi.org/10.2106/JBJS.F.00260.

22. Holtby R, Razmjou H. Impact of work-related compensation claims on surgical outcome of patients with rotator cuff related pathologies: a matched case-control study. J Shoulder Elbow Surg 2010;19:452-60. http://dx.doi.org/10.1016/j. jse.2009.06.011.

23. Harris I, Mulford J, Solomon M, van Gelder JM, Young J. Association between compensation status and outcome after surgery: a meta-analysis. JAMA 2005;293:1644-52. http:// dx.doi.org/10.1001/jama.293.13.1644.

24. Atlas SJ, Tosteson TD, Hanscom B, Blood EA, Pransky GS, Abdu WA et al. What is different about workers' compensation patients? Socioeconomic predictors of baseline disability status among patients with lumbar radiculopathy. Spine (Phila Pa 1976) 2007;32:2019-26.

25. Kragholm K, Odgaard A, Nielsen T, Kolstad H, Andersen J. Poor outcome in patients with spine-related leg or arm pain who are involved in compensation claims: a prospective study of patients in the secondary care sector: comment on the article by Rasmussen et al. Scand J Rheumatol 2009;38:398-9. http:// dx.doi.org/10.1080/03009740902833389.

26. Porta M. Dictionary of epidemiology. 5.ed. Oxford: Oxford Univesity Press; 2008.

27. Signorello LB, McLaughlin JK, Lipworth L, Friis S, Sorensen HT, Blot WJ. Confounding by indication in epidemiologic studies of commonly used analgesics. Am J Ther 2002;9:199205. http://dx.doi.org/10.1097/00045391-20020500000005 . 
28. Psaty BM, Siscovick DS. Minimizing bias due to confounding by indication in comparative effectiveness research: the importance of restriction. JAMA 2010;304:897-8. http:// dx.doi.org/10.1001/jama.2010.1205.

29. National Board of Industrial Injuries. Industrial Injuries. Copenhagen: National Board of Industrial Injuries, 2011.

30. National Board of Industrial Injuries. List of Occupational Diseases reported on or after 1st January 2005. Available online: http://www.ask.dk/en/English/ / /media/ E51232691F974D80BBAD4EFD8D15D484.ashx. Copenhagen: National Board of Industrial Injuries, 2010. Accessed 29 November 2012

31. Jensen LK. Hip osteoarthritis: influence of work with heavy lifting, climbing stairs or ladders, or combining kneeling/ squatting with heavy lifting. Occup Environ Med 2008;65:619. http://dx.doi.org/10.1136/oem.2006.032409.

32. National Board of Industrial Injuries. Arbejdsskadestatistik. [Occupational Injuries Statistics 2011]. Available online: http://www.ask.dk/Statistik/ / /media/30E79DCCC0F14A E1985453BF97A15E40.ashx. Copenhagen: National Board of Industrial Injuries; 2012.

33. Kjuus H, Falkum E, Leira HL, Haanes JV, Moen BE, Ulvestad B et al. Yrkessykdommer. Yrkessykdomsutvalgets utredning av hvilke sykdommer som bør kunne godkjennes som yrkessykdom. [Occupational diseases. Report by the occupational disease committee on which diseases should be recognized as occupational diseases]. Oslo: Norges Offentlige Utredninger; 2008.

34. Arbejdsdirektoratet. Dansk Fagkode [Danish classification of occupations]. Copenhagen: Arbejdsdirektoratet, 1986.

35. Johansen JP. Journalregistrering i arbejdsmedicinen (Record registration in occupational medicine). Copenhagen: Arbejdsmiljøfondet; 1983.

36. Ware JE. Measuring patients' views: the optimum outcome measure. bmj 1993;306:1429-30.
37. Bjørner JB, Damsgaard MT, Watt T, Bech P, Rasmussen N, Kristensen TS et al. Danish manual for SF-36. Copenhagen: LIF; 1997.

38. Jensen LD, Frost P, Schiottz-Christensen B, Maribo T, Christensen MV, Svendsen SW. Predictors of vocational prognosis after herniated lumbar disc: a two-year follow-up study of 2039 patients diagnosed at hospital. Spine (Phila Pa 1976) 2011;36:E791-E797.

39. Mickey RM, Greenland S. The impact of confounder selection criteria on effect estimation. Am J Epidemiol 1989;129:12537.

40. Sinnott P. Administrative delays and chronic disability in patients with acute occupational low back injury. J Occup Environ Med 2009;51:690-9. http://dx.doi.org/10.1097/ JOM.0b013e3181a033b5.

41. Elbers NA, Hulst L, Cuijpers P, Akkermans AJ, Bruinvels DJ. Do compensation processes impair mental health? A meta-analysis. Injury 2012. http://dx.doi.org/10.1016/j. injury.2011.11.025

42. Butterfield PG, Spencer PS, Redmond N, Feldstein A, Perrin N. Low back pain: predictors of absenteeism, residual symptoms, functional impairment, and medical costs in Oregon workers' compensation recipients. Am J Ind Med 1998;34:559-67. http://dx.doi.org/10.1002/(SICI)10970274(199812)34:6<559::AID-AJIM3>3.0.CO;2-3

43. Hansen J. Women with night shift work and breast cancer: the situation in Denmark. J Epidemiol Community Health 2010. http://dx.doi.org/10.1136/jech.2009.101691.

44. Kolstad HA, Erlandsen M, Frost P, Bonde JP. Should we warn against night shift work to prevent breast cancer? Occup Environ Med 2010; Online first.

Received for publication: 10 August 2012 